"This is the peer reviewed version of the following article: Carmona Rodríguez-Acosta, F.; et al. Chemically and Biologically Harmless versus Harmful Ferritin/Copper-Metallothionein Couples. Chemistry A European Journal, 21(2): 808-813 (2015), which has been published in final form at http://dx.doi.org/10.1002/chem.201404660. This article may be used for non-commercial purposes in accordance with Wiley Terms and Conditions for Self-Archiving."

\title{
CHEMICALLY AND BIOLOGICALLY HARMLESS VS. HARMFUL FERRITIN/COPPER-METALLOTHIONEIN COUPLES
}

Fernando Carmona, Daniela Mendoza, Scheghajegh Kord, Michela Asperti, Paolo Arosio, Sílvia Atrian, Mercè Capdevila, Jose M. Dominguez-Vera

Abstract: The simultaneous measurement of the decrease of available Fe ${ }^{I I}$ and the increase of available $\mathrm{Fe}^{\mathrm{III}}$ allowed the analysis of the ferroxidase activity of two distinct apoferritins. Although recombinant human apoferritin ( $\mathrm{HuFtH}$ ) rapidly oxidizes $\mathrm{Fe}^{\mathrm{II}}$ to $\mathrm{Fe}^{\mathrm{III}}$, this is not properly stored in the ferritin cavity, as occurs in horse spleen $\mathrm{H} / \mathrm{L}$-apoferritin ( $\mathrm{HsFt}$ ). Fe storage in these apoferritins was also studied in the presence of two Cu-loaded mammalian metallothioneins (MT2 and MT3), a scenario occurring in different brain cell types. For HuFtH, unstored Fe ${ }^{I I I}$ triggers the oxidation of $\mathrm{Cu}-\mathrm{MT} 2$ with concomitant $\mathrm{Cu}^{\mathrm{I}}$ release. In contrast, for $\mathrm{HsFt}$, there is no reaction with $\mathrm{Cu}-\mathrm{MT} 2$. Similarly, $\mathrm{Cu}-\mathrm{MT} 3$ does not react during either $\mathrm{HuFtH}$ or HsFt Fe reconstitution. Significantly, the combination of ferritin and metallothionein isoforms reported in glia and neuronal cells are precisely those that avoid a harmful release of $\mathrm{Fe}^{\mathrm{II}}$ and $\mathrm{Cu}^{\mathrm{I}}$ ions.

Iron is an essential element for organisms but it is highly toxic in excess. It is well known that free $\mathrm{Fe}^{\mathrm{II}}$ promotes the formation of highly reactive oxygen species capable of causing irreversible cell damage.[1] Organisms have developed chemical machinery based on the ferritin family of proteins to manage the availability of vital, but potentially toxic, free $\mathrm{Fe}^{\mathrm{II}}{ }^{[2-4]}$ Thus, every type of tissue must contain an appropriate type of ferritin $(\mathrm{Ft})$ that scavenges for and stores any Fe which is not required for immediate metabolic purposes. Therefore the Fe is rendered non-toxic and yet still available for when it is required by the cell. The structures of many Ft proteins isolated from a wide range of organisms and biological tissues have been determined. The most extensively studied ferritin is that found in horse spleen, traditionally used as a model for mammalian Ft. It consists of a hollow protein shell composed of 24 subunits arranged in cubic symmetry and has a $\mathrm{Mr}$ of about $450 \mathrm{kDa}$. The shell encapsulates an aqueous cavity of $8 \mathrm{~nm}$ in diameter, capable of accommodating 
thousands of $\mathrm{Fe}$ atoms as an $\mathrm{Fe}^{\mathrm{III}}$ mineral, often described as ferrihydrite, $\left[\mathrm{Fe}^{\mathrm{III}}{ }_{10} \mathrm{O}_{14}(\mathrm{OH})_{2}\right]$. [5]

There are two different types of monomer included in the 24 subunits which compose the Ft shell: the heavy (H) subunits, 178 amino acids and $21 \mathrm{kDa}$, and the light (L) subunits, 171 aminoacids and $19 \mathrm{kDa}$, and each have different functionality. Thus, whereas the $\mathrm{H}$ monomers play a key role in rapid $\mathrm{Fe}$ detoxification, because they contain a catalytic ferroxidase center for FelI oxidation, the $\mathrm{L}$ subunits seem to be associated with $\mathrm{Fe}$ nucleation, mineralization and long-term Fe storage in the ferritin cavity.[2] In accordance with this, the $\mathrm{H} / \mathrm{L}$ ratio in a ferritin shell varies widely in different organisms and different tissues, but it is worth noting that Ft proteins with a combination of $\mathrm{H}$ and L subunits are only found in vertebrates. In this subphylum, L-subunit-rich ferritins predominate in Fe storage organs such as the liver and spleen, whereas organs that require Fe detoxification, such as the heart and most brain cells, contain mostly H-rich ferritins. As an example, horse spleen Ft contains about 90\% L- and 10\% H- subunits. In bacteria, plants and invertebrates, ferritins are exclusively composed of $\mathrm{H}$-like subunits.

To load apoferritin (apoFt), a Ft molecule that does not contain Fe, requires $\mathrm{Fe}^{\mathrm{II}}$ and not, Fe $\mathrm{Fe}^{\mathrm{III}}$ as the substrate. In broad terms, it is accepted that Fe $\mathrm{Fe}^{\mathrm{II}}$ moves through the hydrophilic channels until it finds the ferroxidase center of an $\mathrm{H}$ subunit, here it is catalytically oxidized to $\mathrm{Fe}$ III by reaction with cellular $\mathrm{O}_{2}$. It then moves to the cavity where it is finally stored as a ferrihydrite nanoparticle.[6] The mechanism of the ferroxidase oxidation of $\mathrm{Fe}^{\mathrm{II}}$ to $\mathrm{Fe}^{\mathrm{III}}$, as well as the path of $\mathrm{Fe}$ III from the ferroxidase center to the cavity, are currently a point of controversy. ${ }^{[2,6-10]}$ In any case, if any Fe ${ }^{\mathrm{III}}$ remains at the ferroxidase center, somehow close to the surface of ferritin, some biomolecules could be able to scavenge it. In fact, Hagen et al. have shown that transferrin, a large protein (80 $\mathrm{kDa}$ ) that is unable to enter the Ft cavity, scavenges the two $\mathrm{Fe}^{\mathrm{III}}$ ions of the ferroxidase center. ${ }^{[10]}$ However, in these experiments transferrin just served as an $\mathrm{Fe}^{\mathrm{III}}$ sensor to confirm the nature of the ferroxidase center and the results have little biological relevance because $\mathrm{Ft}$ is basically intracellular, whereas transferrin is the plasma Fe ${ }^{I I I}$ transport protein.

Considering this background, and with the aims of, (a) gaining further insight 
into the biological consequences of ferroxidase center function, and (b) correlating the apoferritin composition resulting Fe ${ }^{\mathrm{III}}$ unavailable, we decided to study how Fe $\mathrm{FI}^{\mathrm{II}}$ is oxidized by two apoFts with different H/L ratios: recombinant human $\mathrm{H}$-apoFt (HuFtH), a homopolymer of 24 identical $\mathrm{H}$ - subunits each with a ferroxidase center, and the commonly studied horse spleen apoFt (HsFt), a heteropolymer formed of approximately $3 \mathrm{H}$ - and $21 \mathrm{~L}$-subunits (L-subunits lack the ferroxidase center). The Fe ${ }^{\mathrm{II}}$ to Fe $\mathrm{Fe}^{\mathrm{III}}$ oxidation activities of $\mathrm{HuFtH}$ and $\mathrm{HsFt}$, and their capacities to make the formed Fe ${ }^{I I I}$ unavailable, were studied by following a very simple protocol. This was based on monitoring the decrease of available $\mathrm{Fe}^{\mathrm{II}}$, and the increase of available $\mathrm{Fe}^{\mathrm{III}}$, in a batch of 15 fresh samples initially containing $\mathrm{Fe}^{\mathrm{II}}$ and the respective apoFts in catalytic proportions (approx. 200 $\mathrm{Fe}^{\mathrm{II}}$ /apoFt). The addition, at different reaction times, of an excess of ferrozine (fz) or apolactoferrin (Lf) serves as an indicator, via measurement of the respective UV-vis absorbances at $562 \mathrm{~nm}\left(\left[\mathrm{Fe}^{\mathrm{II}}(\mathrm{fz})^{3}\right]^{2+}\right)$ or $464 \mathrm{~nm}$ (Fe ${ }^{\text {III-Lf }}$ ), of the concentration of available $\mathrm{Fe}^{\mathrm{II}}$ or $\mathrm{Fe}^{\mathrm{III}}$ at every step of the Ft reconstitution process. The combination of $\mathrm{Fe}^{\mathrm{II}}$ decrease and $\mathrm{Fe}^{\mathrm{III}}$ increase availability patterns provides a dynamic picture of the overall Fe uptake process carried out by Ft. Hence, monitoring $\left(\left[\mathrm{Fe}^{\mathrm{II}}(\mathrm{fz})^{3}\right]^{2+}\right)$ concentration, i.e., recording the time dependence of $A^{562 \mathrm{~nm}}$ allows evaluation of the capability of each apoFt to oxidize $\mathrm{Fe}^{\mathrm{II}}$ because the faster is the Fe $\mathrm{FI}^{\mathrm{II}}$ oxidation process, the faster is the decrease of the UV-vis absorbance at $562 \mathrm{~nm}$. As shown in Figure 1, the free Fe ${ }^{I I}$ concentration decreases in the presence of $\mathrm{HsFt}$ (L-rich) to reach a plateau corresponding to a remaining $40 \%$ of the initial $\mathrm{Fe}^{\mathrm{II}}$, while the decrease of free $\mathrm{Fe}^{\mathrm{II}}$ in the presence of HuFtH (entirely H-subunits) is significantly higher, so that within a few minutes almost all the initial $\mathrm{Fe}^{\mathrm{II}}$ is no longer available to react with fz. These results corroborate the idea that the ferroxidase activity of apoFt increases with its $\mathrm{H} / \mathrm{L}$ ratio, as activity is clearly higher for HuFtH than for HsFt. 


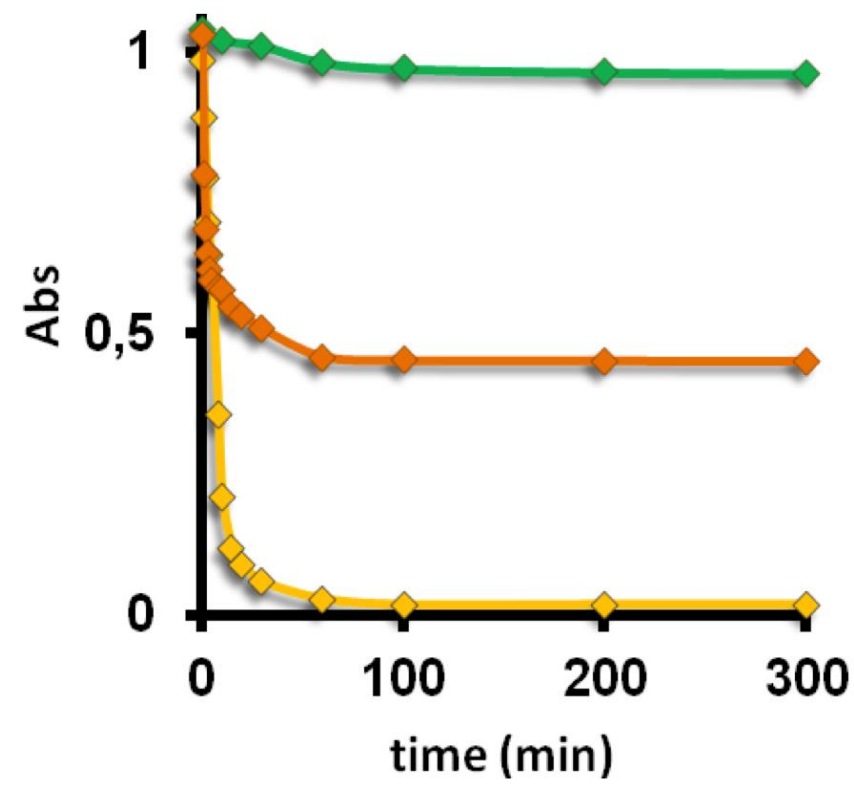

Figure 1. Fe(II) availability in the presence of two different apoFts: Absorbance at $562 \mathrm{~nm}$, i.e. $\left[\mathrm{Fe}^{\mathrm{II}}(\mathrm{fz})^{3}\right]^{2+}$ concentration, after addition, at different times, of ferrozine to the mixtures HsFt $+\mathrm{Fe}^{\mathrm{II}}$ (orange) and HuFtH $+\mathrm{Fe}^{\mathrm{II}}$ (yellow). Green data correspond to the control (absence of protein). As shown in the control, under our experimental conditions, $\mathrm{Fe}^{\mathrm{II}}$ remains stable in solution at least 300 minutes.

An analogous batch of experiments was performed but Lf in the presence of bicarbonate was added instead of fz, (see Experimental). Monitoring the UV-vis

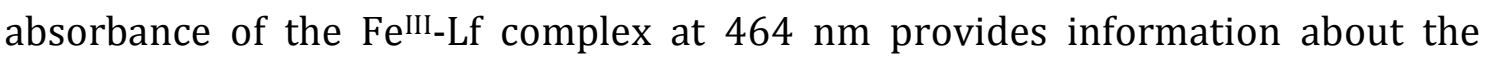
concentration of available Fe ${ }^{I I I}$ produced by the Ft reconstitution process. As can be seen in Figure 2, HsFt does not yield any peaks at this wavelength, suggestive of the low availability of Fe ${ }^{I I I}$ formed by this apoFt, whereas HuFtH gives rise to the development of the UV-vis band at $464 \mathrm{~nm}$ typical of Fe $\mathrm{e}^{\mathrm{III}}$-Lf, and which is independent of the allowed Fe ${ }^{\mathrm{II}}$-HuFtH reaction time. This absorbance correlates with a permanent concentration of $0.16 \mathrm{mM}$ of free $\mathrm{Fe}^{\mathrm{III}}$, which corresponds to almost $50 \%$ of the $\mathrm{Fe}^{\mathrm{II}}$ that was allowed to react with HuFtH.

According to previous reports on this subject, we cannot rule out the possibility of a small fraction of the initial $\mathrm{Fe}^{\mathrm{II}}$ being stabilized in the ferritin cavity and therefore unavailable for $\mathrm{fz}$ complexation.[11] However, the rapid increase of 
$\mathrm{A}^{464 \mathrm{~nm}}$ due to the formation of Fe $\mathrm{III}$ - Lf in the presence of HuFtH confirms that for this protein, $\mathrm{Fe}^{\mathrm{II}}$ is not available for $\mathrm{fz}$ complexation because a large proportion of the initial Fe ${ }^{\mathrm{II}}$ is actually oxidized to Fe ${ }^{\mathrm{III}}$ rather than stabilized within the protein as FeII. In either case, the presence or absence of a small fraction of stabilized Fe ${ }^{I I}$ within the ferritin cavity is neither the focus of this work nor is it crucial for the conclusions which wewill draw, our focus is on the presence/absence of available Fe $\mathrm{Fe}^{\mathrm{III}}$ during the Ft mineralization process. In this context, our results clearly demonstrate that once $\mathrm{Fe}^{\mathrm{II}}$ is oxidized by HsFt, the resulting $\mathrm{Fe}^{\mathrm{III}}$ is in an inaccessible form, probably because these Fe $\mathrm{F}^{\mathrm{III}}$ ions are stored inside the protein cavity and Lf is too large to pass through the Ft channels to bind Fe $\mathrm{FII}^{\mathrm{II}}$. However, although HuFtH oxidizes practically all of the initial Fe $\mathrm{Fe}^{\mathrm{II}}$, half of the formed Fe $\mathrm{F}^{\mathrm{II}}$ is available to large biomolecules such as Lf. Furthermore, according to our results and contrasting them with those reported by Hagen et al.,[10] the amount of $\mathrm{Fe}^{\mathrm{III}}$ complexed by Lf during the Fe reconstitution process of $\mathrm{HuFtH}$ is almost double than that corresponding to the number of Fe atoms at the ferroxidase centers (24 x 2 per protein). Here, the protein is present in catalytic quantities, and therefore a large excess of $\mathrm{Fe}^{\mathrm{II}}$ has been added (a situation that is probably closer to the actual in vivo scenario) and so we can conclude that the target of Lf is probably not only the Fe $\mathrm{F}^{\mathrm{III}}$ ions fixed at the ferroxidase centers but also the Fe III cations formed at such centers and which are not really stored by HuFtH within the protein cavity. This protein, therefore, conclusively exhibits high ferroxidase activity but a low Fe storage capacity. 

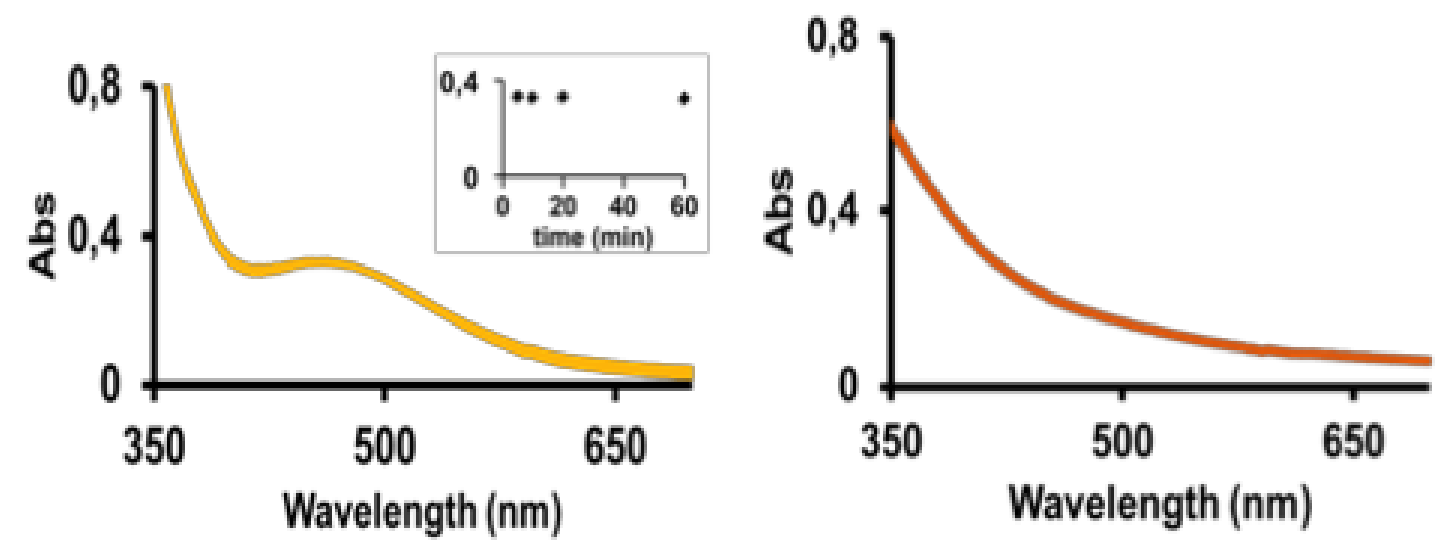

Figure 2. Fe III availability after oxidation of Fe ${ }^{I I}$ by two different apoFt proteins: $U V$-vis spectra after addition, at different times, of lactoferrin to the mixtures $H u F t H+F e^{I I}$ (left) and HsFt $+F e^{I I}$ (right). The inset corresponds to the time dependence of the absorbance at $464 \mathrm{~nm}$, i.e. [Fe III-Lf] concentration.

In contrast, HsFt exhibits low ferroxidase activity but with a high $\mathrm{Fe}^{\mathrm{III}}$ storage capacity since we did not observe Fe with Lf, thus indicating that although relatively little Fe $\mathrm{FII}^{\mathrm{III}}$ is formed, it is genuinely stored within the ferritin cavity (i.e., it is not available for a chelating agent). More interestingly, and in a second stage of this work, we focused on the biological relevance of our results by investigating some of the chemical consequences of the observed Fe $\mathrm{F}^{\mathrm{III}}$ availability during reconstitution of Ft. We tried to go one step further beyond the demonstration that once $\mathrm{Fe}^{\mathrm{II}}$ has been oxidized at the ferroxidase center of $\mathrm{Ft}$, some $\mathrm{Fe}{ }^{\mathrm{III}}$ ions can then be scavenged by an Fe III chelator. If, according to the present results and those of Hagen et al.,[10] $\mathrm{Fe}^{\mathrm{III}}$ produced in the Ft ferroxidase center is available for complexation by a large molecule such as transferrin, it should also be able to act as an oxidant against metallothioneins (MTs).[12] This possibility takes special relevance in view of the Fenton reactivity of $\mathrm{Cu}^{\mathrm{I} / \mathrm{II}}$ ions and the widely assumed presence of $\mathrm{Cu}$-containing MTs in brain cells. Bearing this in mind, we studied the Fe reconstitution of the two different ferritins from our study (HuFtH and $\mathrm{HsFt}$ ) in the presence of the Cu-loaded forms of two mammalian MT isoforms (MT2 and MT3). MTs are small (6 - $10 \mathrm{kDa}$ ) and cysteine rich (33\%) metaloproteins. They are naturally found bound to either $\mathrm{Zn}^{\mathrm{II}}$ and/or $\mathrm{Cu}^{\mathrm{I}}$ but their biological function is still a matter of debate although they are accepted as 
major players in the homeostasis of physiological $\mathrm{Zn}$ and $\mathrm{Cu}^{[13,14]}$ We paid particular attention to MT2 and MT3 because the former is predominantly synthesized in astrocytes and microglia, where ferritin is mainly found in the Lrich form, while the latter is a brain-specific isoform constitutively expressed in neurons, where H-rich ferritins are predominant. ${ }^{[15,16]}$ Therefore, the coexistence of certain combinations of Ft and MT (i.e., MT2 with L-rich or MT3 with H-rich ferritins) can be considered to be a direct reflection of the situation encountered in different types of brain cells. In accordance with the Zn-thionein character of $\mathrm{MT}^{[17]}$ and the partial Cu-thionein character of $\mathrm{MT}^{[18,19]}$ they would constitute mixed $\mathrm{Zn}, \mathrm{Cu}-\mathrm{MT}$ complexes (instead of homonuclear Cu-MT species) when synthesized in the brain, even in the presence of physiologically high $\mathrm{Cu}$ concentrations. For this reason we used the metal-MT2 and metal-MT3 preparations that result from the recombinant synthesis of MT2 and MT3 in Cusupplemented E. coli cultures grown under regular aeration, ${ }^{[20]}$ which is the closest approximation to mammalian cell conditions. They yielded a mixture of $\mathrm{Zn}_{1} \mathrm{Cu}_{10^{-}}$and $\mathrm{Zn}_{2} \mathrm{Cu}_{10^{-}}$as major species for $\mathrm{MT}^{[17]}$ and a mixture of $\mathrm{Zn}_{4} \mathrm{Cu}_{6^{-}}$and $\mathrm{Cu}_{10}$-complexes for $\mathrm{MT}^{[18]}$, which from now on and for the sake of simplicity we shall refer to as the Cu-MT2 and Cu-MT3 complexes.

For these experiments, we prepared a batch of $\mathrm{Fe}^{\mathrm{II}}$-apoFt mixtures with HsFt and with $\mathrm{HuFtH}$, and allowed them to react aerobically for 15 minutes. These reaction mixtures were then degassed and saturated with argon prior to the addition of the $\mathrm{Cu}$-loaded forms of MT2 or MT3 with the appropriate chelating agent, either BTA or fz. The $\mathrm{Cu}^{\mathrm{I}}$ released or the $\mathrm{Fe}^{\mathrm{II}}$ formed as a result of the oxidation of the $\mathrm{Cu}-\mathrm{MTs}$ by $\mathrm{Fe}^{\mathrm{II}}$ could be respectively determined by monitoring the UV-vis absorbance at either $480 \mathrm{~nm}\left(\mathrm{Cu}^{\mathrm{I}}-\mathrm{BTA}\right)$ or $562 \mathrm{~nm}\left(\left[\mathrm{Fe}^{\mathrm{II}}(\mathrm{fz})^{3}\right]^{2+}\right)$ with time. 


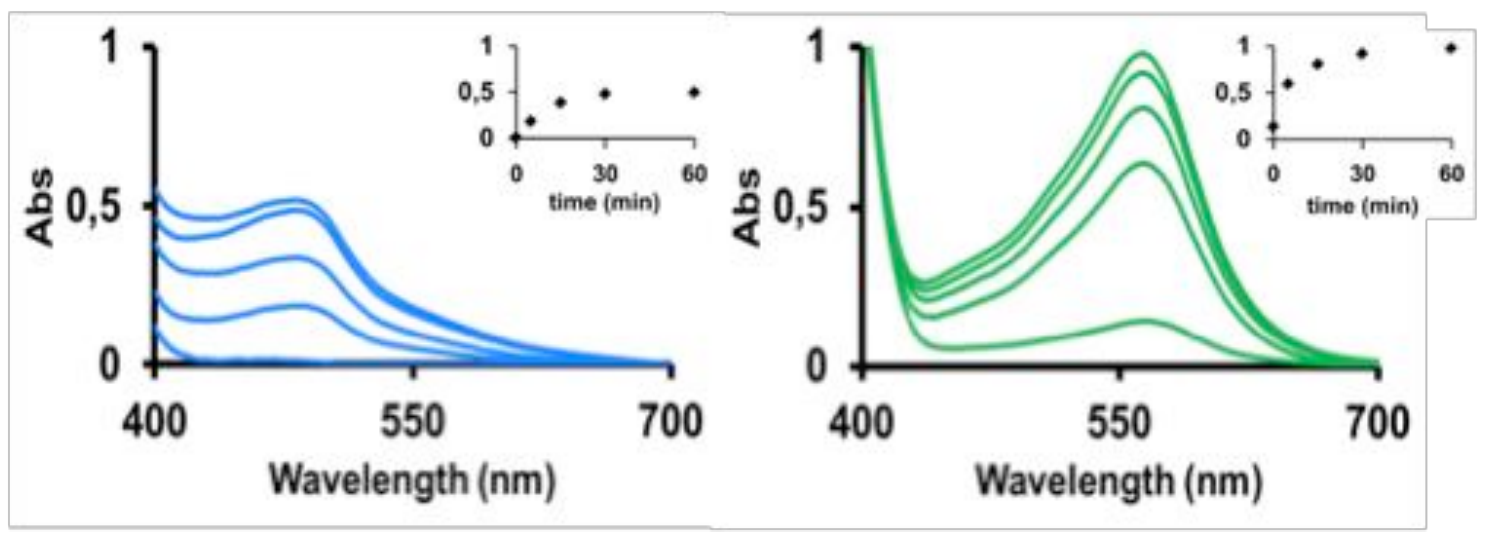

Figure 3. UV-vis spectra recorded at different times after the addition of Cu-MT2 + BTA (left) and Cu-MT2 + fz (right) to a mixture of HuFtH + Fe ${ }^{I I}$. Insets correspond to the time dependence of the absorbance at $480 \mathrm{~nm}$ (left) and $562 \mathrm{~nm}$ (right).

Based on the initial $\mathrm{Cu}$ concentration of the $\mathrm{Cu}-\mathrm{MT} 2$ sample $(41 \mu \mathrm{M})$, it can be concluded that almost $90 \%$ of $\mathrm{Cu}$ was removed from MT2 after 30 min of reaction $\left(35,7 \mu \mathrm{M}\right.$ final concentration of $\left.\mathrm{Cu}^{\mathrm{I}}-\mathrm{BTA}\right)$. The same reaction with $\mathrm{Cu}$ MT3 released only $6 \%$ of the initially coordinated $\mathrm{Cu}$. However, the parallel study of HsFt is dramatically different; no absorbance peak developed at 480 $\mathrm{nm}$, highlighting the absence of free $\mathrm{Cu}^{\mathrm{I}}$ since, in agreement with the high $\mathrm{Fe}$ storage capacity of HsFt, there is a very low availability of $\mathrm{Fe}^{\mathrm{III}}$ in the medium to oxidize either $\mathrm{Cu}-\mathrm{MT} 2$ or $\mathrm{Cu}-\mathrm{MT} 3$.

It is therefore reasonable to assume that the $\mathrm{Fe}^{\mathrm{III}}$ formed after oxidation at the $\mathrm{HuFtH}$ ferroxidase center is the agent responsible for oxidizing $\mathrm{Cu}-\mathrm{MT} 2$ on the basis of three different experiments: (i) The mixtures of $\mathrm{HuFtH}, \mathrm{Cu}-\mathrm{MT} 2 / \mathrm{Cu}$ MT3 and BTA do not exhibit any significant UV-vis absorption corresponding to $\mathrm{Cu}^{\mathrm{I}}$-BTA in the absence of $\mathrm{Fe}^{\mathrm{II}}$. This points out that, in the absence of $\mathrm{Fe}^{\mathrm{II}}$, neither MT2 nor MT3 are oxidized. (ii) Addition of an $\mathrm{Fe}^{\text {III }}$ salt, in the same concentration as that generated in the $\mathrm{Fe}^{\mathrm{II}}+\mathrm{HuFtH}$ experiment, to an anaerobic Cu-MT2 solution, but not in one containing Cu-MT3, in the presence of BTA produces $\mathrm{Cu}^{\mathrm{I}}$-BTA with a $\mathrm{Cu}^{\mathrm{I}}$ delivery pattern similar to that of the $\mathrm{Fe}^{\mathrm{II}}+\mathrm{HuFtH}+$ Cu-MT2 experiment (see Experimental). This clearly indicates that $\mathrm{Fe}^{\mathrm{III}}$ is a powerful oxidant capable of oxidizing the mammalian MT2 isoform in its $\mathrm{Cu}$ loaded form, while that of MT3 practically resists this oxidizing environment. (iii) When HuFtH is incubated with $\mathrm{Fe}^{\mathrm{II}}$ and after 15 min of reaction (once the $\mathrm{Fe}^{\mathrm{II}}$ 
oxidation is almost complete, Figure 1) Cu-MT2 -together with fz- is added to the reaction mixture, the $\left(\left[\mathrm{Fe}^{\mathrm{II}}(\mathrm{fz})^{3}\right]^{2+}\right)$ complex forms and its concentration increases with time (Figure 3). This final experiment evidences that after the reduction of the $\mathrm{Fe}^{\mathrm{II}}$ concentration to almost zero during the Fe reconstitution process of $\mathrm{HuFtH}$, reaction upon addition of $\mathrm{Cu}-\mathrm{MT} 2$ again raises the $\mathrm{Fe}^{\mathrm{II}}$ concentration to $59 \%$ of the initial value as a consequence of the oxidation of MT2 by Fe $\mathrm{e}^{\text {III }}$.

In summary, in this paper we demonstrate that part of the $\mathrm{Fe}^{\mathrm{III}}$ formed at the ferroxidase centers of HuFtH is available, not only for complexation with an Fe $\mathrm{F}^{\text {III }}$ chelator, but also to oxidize $\mathrm{Cu}$-loaded MT2, giving rise to the concomitant release of two toxic metals ions, $\mathrm{Cu}^{\mathrm{I}}$ and $\mathrm{Fe}^{\mathrm{II}}$. The latter reaction does not take place when the apoferritin is a H/L heteropolymer such as HsFt. In this case, all the $\mathrm{Fe}^{\mathrm{III}}$ formed at the ferroxidase center is unavailable for either Lf complexation or MT oxidation. The chemical scenario we have created is especially significant in the brain, where incorrect Fe uptake by $\mathrm{Ft}$ has been suggested to result in the progression of neurological diseases. Hence, Dobson and co-workers proposed that patients with Alzheimer's disease could have a dysfunction in brain Fe storage due to a disruption in the balance of ferritin $\mathrm{H}$ and L- subunit synthesis. ${ }^{[21]}$ In this sense, our results point out that in cells where $\mathrm{Cu}-\mathrm{MT} 2$ and Ft coexist, there is no danger if the ferritin is L-rich, as it occurs in astrocytes and microglia, ${ }^{[16]}$ and both proteins would preserve their integrity and functionality. However, if this imbalance in L- and H-subunit synthesis leads to the synthesis of pure $\mathrm{H}$ apoferritins, and therefore to some events analogous to those we have described here in which the high ferroxidase activity and low Fe storage capacity of a $\mathrm{H}$-rich $\mathrm{Ft}$ would provoke $\mathrm{Cu}^{\mathrm{I}}$ liberation from $\mathrm{Cu}-\mathrm{MT} 2$, then the presence of two free and toxic metals such as $\mathrm{Cu}^{\mathrm{I}}$ and $\mathrm{Fe}^{\mathrm{II}}$, could produce fatal results for the cell. Interestingly, Cu-MT3 does not react with either HuFtH or HsFt in the presence of $\mathrm{Fe}^{\mathrm{II}}$ thus making the Cu-MT3 and Ft pair a nondeleterious combination in neurons. This is extremely relevant because in neuron cells Ft is mainly present in H-rich forms, ${ }^{[16]}$ which would lead to a harmful interaction should the predominant MT isoform present be that of MT2. What we wish to underline here is that the process of Fe storage in ferritin affects parallel metal metabolisms depending on the protein shell itself. Following on from that we have shown that an excessive proportion of $\mathrm{H}$-subunits in the ferritin shell 
results in a significant decrease in the amount of Fe stored, meaning that there is free $\mathrm{Fe}^{\mathrm{III}}$ available that is capable of oxidizing $\mathrm{Cu}-\mathrm{MT} 2$, ultimately leading to the liberation of toxic $\mathrm{Fe}^{\mathrm{II}}$ and $\mathrm{Cu}^{\mathrm{I}}$. As a final conclusion, it is worth highlighting that the current results reconcile the simultaneous presence of ferritins and MT in cells, ${ }^{[12]}$ provided that the correct combination of isoforms is preserved, otherwise metal-related neuronal disorders could be triggered if parting from this ideal combination.

\section{Experimental Section}

Materials. Horse spleen apoFt (HsFt) was obtained from Sigma and was exhaustively dialyzed against Milli-Q water using a Spectra/Por Float-A-Lyzer with a molecular weight cut off (MWCO) of 300,000 Da. Recombinant human H-Ft (HuFtH) was prepared as previously described ${ }^{[21,22]}$ and rendered iron free by dialysis against sodium hydrosulfite (dithionite), $\mathrm{Na}_{2} \mathrm{~S}_{2} \mathrm{O}_{4}$, and complexation with 2,2'-bipyridyl at $\mathrm{pH} 6.0^{[23]}$, to isolate an apoferritin containing $10 \mathrm{Fe} /$ protein. The $\mathrm{Cu}$ loaded forms of the mammalian metallothionein isoforms MT2 and MT3 were recombinantly synthesized and characterized (ICP-AES and ESI-MS) as previously reported. ${ }^{[17,18]}$ The final preparations were $0.13 \times 10^{-4} \mathrm{M}$ (MT2) and $0.35 \times 10^{-4}$ $\mathrm{M}$ (MT3) in $50 \mathrm{mM}$ Tris-HCl, pH 7.5 buffer, and they were deaerated under $\mathrm{N}_{2}$ flux to avoid the presence of $\mathrm{O}_{2}$ during the described reactions. Monoferric lactoferrin was purchased from Fonterra. Lf was prepared following the same protocol as reported previously. ${ }^{[24]}$

Measurement of available $\mathrm{Fe}^{I I}$. Batches of 15 fresh solutions for each type of apoferritin, $0.2 \mu \mathrm{M}$ in 0.15 M HEPES buffer, $\mathrm{pH}$ 7.0, and fresh aqueous solutions of $\mathrm{Fe}\left(\mathrm{SO}_{4}\right)_{2}\left(\mathrm{NH}_{4}\right) \cdot 6 \mathrm{H}_{2} \mathrm{O}$ (final $\mathrm{Fe} 0.0353 \mathrm{mM}$ ) were mixed. $1 \mathrm{~mL}$ of an aqueous ferrozine solution (3-(2-pyridyl)-5,6-diphenyl-1,2,4-triazine-p,p-disulfonic acid monosodium salt hydrate, Aldrich), final concentration $0.935 \mathrm{mM}$, was added to every sample after $1,2,3,4,5,8,10,15,20,30,60,100,200$ and $300 \mathrm{~min}$ and the UV-visible spectra immediately recorded. Available $\mathrm{Fe}^{\mathrm{II}}$ concentration was calculated for every sample in the batch from the UV-vis absorbance measured at $562 \mathrm{~nm}$, due to formation of the $\left(\left[\mathrm{Fe}^{\mathrm{II}}(\mathrm{fz})_{3}\right]^{2+}\right)$ complex $\left(\varepsilon=27,900 \mathrm{M}^{-1} \mathrm{~cm}^{-1}\right)$. 
Measurement of available Fe $e^{I I I}$. A batch of four fresh solutions of each apoferritin,

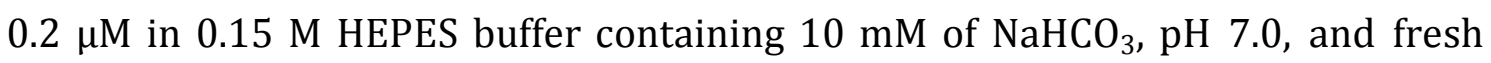
aqueous solutions of $\mathrm{Fe}\left(\mathrm{SO}_{4}\right)_{2}\left(\mathrm{NH}_{4}\right) \cdot 6 \mathrm{H}_{2} \mathrm{O}$ (final $\mathrm{Fe} 0.353 \mathrm{mM}$ ) were mixed. 200 $\mu \mathrm{L}$ of an aqueous solution of Lf (final concentration $200 \mu \mathrm{M}$ ) was added to every sample after 5, 10, 20 and $60 \mathrm{~min}$ and the UV-vis spectra recorded. Available Fe III concentration was calculated for every sample of the batch from the UV-vis absorbance measured at $464 \mathrm{~nm}$, due to formation of the [Fe $\left.{ }^{\mathrm{III}}(\mathrm{Lf})\right]$ complex $(\varepsilon=$ 2,600 $\left.\mathrm{M}^{-1} \mathrm{~cm}^{-1}\right)$.

Measurement of $\mathrm{Cu}^{I}$ during ferritin reconstitution in the presence of Cu-MT. In a parallel experiment, HuFtH and HsFt $(0.2 \mu \mathrm{M})$ in 0.15 M HEPES buffer, pH 7.0, were incubated with aqueous solutions of $\mathrm{Fe}\left(\mathrm{SO}_{4}\right)_{2}\left(\mathrm{NH}_{4}\right) \cdot 6 \mathrm{H}_{2} \mathrm{O}$ (final [Fe] 0.035 $\mathrm{mM}$ ) at $37^{\circ} \mathrm{C}$ and in aerobic conditions for $15 \mathrm{~min}$. The reaction mixture was then totally deoxygenated under nitrogen flux and kept under an anaerobic atmosphere prior to the addition of Cu-MT2 $(100 \mu \mathrm{L}, 5.2 \mu \mathrm{M},[\mathrm{Cu}] 41 \mu \mathrm{M})$ or $\mathrm{Cu}$ MT3 $(100 \mu \mathrm{L}, 4.7 \mu \mathrm{M}, \quad 40 \mu \mathrm{M})$. Then, $10 \mu \mathrm{L}$ of $0.4 \quad \mathrm{mM}$ BTA (bathocuproinedisulfonic acid disodium salt) was added to the mixture in order to detect $\mathrm{Cu}^{\mathrm{I}}$ by observation of the UV-vis band at $480 \mathrm{~nm}$ due to formation of the $\left[\mathrm{Cu}^{\mathrm{I}}(\mathrm{BTA})_{2}\right]^{+}$complex $\left(\varepsilon=14,000 \mathrm{M}^{-1} \mathrm{~cm}^{-1}\right)$. The same experiments carried out in the absence of $\mathrm{Fe}^{\mathrm{II}}$ did not produce an absorbance peak at $480 \mathrm{~nm}$ for the UV-vis spectra of $\left[\mathrm{Cu}^{\mathrm{I}}(\mathrm{BTA})_{2}\right]^{+}$.

Measurement of $\mathrm{Fe}^{I I I}$ reduction to Fe during HuFtH ferritin reconstitution in the presence of $\mathrm{Cu}-\mathrm{MT2}$. The previous protocol was followed but using ferrozine instead of BTA as a chelating agent for the purposes of measuring the $\mathrm{Fe}^{\text {II }}$ concentration. We noted that after $15 \mathrm{~min}$ of $\mathrm{Fe}^{\mathrm{II}}$ reconstitution by $\mathrm{HuFtH}$, the $\mathrm{Fe}^{\text {II }}$ concentration had dramatically decreased (Figure 1). Therefore the increase of $\mathrm{Fe}^{\mathrm{II}}$ concentration in this experiment corresponds to the oxidation of Cu-MT2 by $\mathrm{Fe}^{\mathrm{III}}$ with the subsequent formation of $\mathrm{Fe}^{\mathrm{II}}$, which is ultimately detected and quantified by its complexation with fz.

Oxidation of Cu-MT by Fe ${ }^{I I I}$. In a parallel experiment, Cu-MT2 $(100 \mu \mathrm{L}, 3 \mu \mathrm{M})$ and Cu-MT3 $(100 \mu \mathrm{L}, 3 \mu \mathrm{M})$ were incubated at $37^{\circ} \mathrm{C}$ in a degassed aqueous solution of $\mathrm{Fe}^{\mathrm{III}}$ acetate $(0.02 \mathrm{mM})$ under Ar. BTA or fz was added to detect and quantify the $\mathrm{Cu}^{\mathrm{I}}$ or $\mathrm{Fe}^{\mathrm{II}}$ concentrations. 


\section{Acknowledgements}

Work supported by the Spanish MINECO and FEDER funds with grants CTQ201232236 to J.M. Domínguez-Vera, BI02012-39682-C02-01 to S. Atrian, and BI0201239682-C02-02 to M. Capdevila. The authors from the Barcelona universities are members of the Grup de Recerca de la Generalitat de Catalunya refs. 214SGR00423. F. C. is grateful to the Spanish MINECO for a FPI Fellowship. We thank the Centres Científics i Tecnològics (CCiT) of the Universitat de Barcelona (ICP-AES) and the Servei d'Anàlisi Química (SAQ) of the Universitat Autònoma de Barcelona (ESI-MS) for allocating instrument time. S. Artime, working at S. Atrian's laboratory, was responsible for the recombinant syntheses of the $\mathrm{Cu}-\mathrm{MT}$ preparations.

Keywords: Ferritin $\bullet$ Metallothionein $\bullet$ Ferroxidase activity $\bullet$ Fe metabolism

\section{References}

[1] a) K. Jomova, M. Valko, Curr. Pharm. Des. 2011, 17, 3460-3473. b) H. Heli, S. Mirtorabi, K. Karimian, Expert Opinion on Therapeutic Patents 2011,21, 819.

[2] a) E. C. Theil, Curr. Opin. Chem. Biol. 2011, 15, 304-311; b) X. F. Liu, E. C.Theil, Acc. Chem. Res. 2005, 38, 167-175.

[3] F. Bou-Abdallah, Biochim. Biophys. Acta 2010, 1800, 719-731.

[4] F. Carmona, O. Palacios, N. Gálvez, R. Cuesta, S. Atrian, M. Capdevila, J. M. Domínguez-Vera, Coord. Chem. Rev. 2013, 257, 2752- 2764.

[5] N. D. Chasteen, P. M. Harrison, J. Struct. Biol. 1999, 126, 182-194.

[6] J. M. Bradley, G. R. Moore, N. E. Le Brun, J. Biol. Inorg. Chem. 2014, DOI

10.1007/soo775-014-1136-3 and references therein.

[7] X. Liu, E. C. Theil, Proc. Natl. Acad. Sci. U.S.A. 2004, 101, 8557-8562.

[8] P. Arosio, R. Ingrassia, P. Cavadini, Biochim. Biophys. Acta, 2009, 1790, 589599. 
[9] F. Bou-Abdallah, G. Zhao, H. R. Mayne, P. Arosio, N. D. Chasteen, J. Am. Chem. Soc. 2005, 127, 3885-3893.

[10] H. K. Ebrahimi, E. Bill, P. L. Hagedoorn, W. R. Hagen, Nat. Chem. Biol. 2012, 8, 941-948.

[11] J. S. Rohrer, R. B. Frankel, G. C. Papaefthymiou, E. C. Theil, Inorg. Chem. 1989, 28, 3393-3395.

[12] R. Orihuela, B. Fernández, Ò. Palacios, E. Valero, S. Atrian, R. K. Watt, J. M. Domínguez-Vera, M. Capdevila, Chem. Commun. 2011, 47, 12155-12157.

[13] M. Capdevila, R. Bofill, Ò.Palacios, S. Atrian, Coord. Chem. Rev. 2012, 256, 4652.

[14] Ò. Palacios, S. Atrian, M. Capdevila, J. Biol. Inorg. Chem. 2011;16, 991-1009.

[15] B. A. Masters, C. J. Quaife, J. C. Erickson, E. J. Kelly, G.J. Froelick, B.P. Zambrowicz, R.L. Brinster, R.D. Palmiter, J. Neurosci. 1994, 14, 5844-5857.

[16] P. Ponka, C. Beaumont, D. Richardson, Semin. Hematol. 1998, 35, 35.

[17] E. Artells, Ò. Palacios, M. Capdevila, S. Atrian, Metallomics 2013, 5, 1397-1410.

[18] E. Artells, Ò. Palacios, M. Capdevila, S. Atrian, FEBS J 2014, 281, 1659-1678.

[19] G. Meloni, V. Sonois, T. Delaine, L. Guilloreau, A. Gillet, J. Teissié, P. Faller, M. Vašák, Nat Chem Biol. 2008, 4; 366-372.

[20] A. Pagani, L. Villarreal, M. Capdevila, S. Atrian, Mol. Microbiol. 2007, 63, 256269.

[21] Q. Q. Pankhursta, D. Hautotb, N. Khanc, J. Dobson, J. Alzheimers Dis. 2008, 13, 49-Pagina final.

[22] P. Santambrogio, A. Cozzi, S. Levi, E. Rovida, F. Magni, A. Albertini, P. Arosio, Protein Expression Purification 2000, 19, 212-218.

[23] E. R. Bauminger, P. M. Harrison, D. Hechel, I. Nowik, A. Treffry, Biochim. Biophys. Acta, 1991, 1118, 48-58.

[24] F. Carmona, V. Muñoz-Robles, R. Cuesta, N. Gálvez, M. Capdevila, J-D. Maréchal, J. M. Dominguez-Vera, J. Biol. Inorg. Chem. 2014, 19, 439-447. 